\title{
Effect Of Liability Of Foreignness And Family Ownership On Cross-Listing Location Choice
}

He Soung Ahn, Korea University Business School, South Korea Hyejin Cho, Korea University Business School, South Korea

\begin{abstract}
Firms incur liability of foreignness (LOF) when they expand their businesses to foreign countries. This study examines the applicability of LOF in the context of financing in a foreign capital market. Using an alternative-specific conditional logit model, we investigate the cross-listing decisions of firms from 28 countries that select among eight target destinations from 1994 to 2008. These firms target capital markets with lower LOF, which is measured by institutional, economic, geographic, and cultural distance. Such preference is particularly stronger for firms with higher levels of family ownership, suggesting family owners' tendency to be averse to risk is also manifested in financing context.
\end{abstract}

Keywords: Cross-Listing; Liability of Foreignness; International Capital Market; Family Ownership

\section{INTRODUCTION}

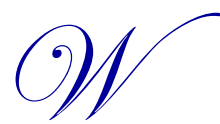
ith the increasing cross-border flows of capital, many firms have begun to cross-list their stocks in foreign capital markets to pursue the associated benefits, such as low cost of capital, high liquidity in stock trading, and increased reputation (Karolyi, 2006). However, cross-listing in foreign markets has several disadvantages, such as the high costs from the "home bias," investors' preference to hold domestic stocks over comparable foreign stocks (Cooper \& Kaplanis, 1994, Dahlquist, Pinkowitz, Stulz, \& Williamson, 2003, French \& Poterba, 1991, Tesar \& Werner, 1995). The home bias in a capital market, which describes the perspectives of investors (Hejazi, 2007), resembles the concept of liability of foreignness (LOF) from the international business literature.

Building on the notion that the concept of LOF in product markets is also applicable to capital markets (Bell, Filatotchev, \& Rasheed, 2012), our aim is to test whether LOF can influence cross-listing location decisions and whether different ownership structures, particularly family ownership, can affect such relationship. Despite the prevalence of cross-listings in the US capital market, cross-listing is not limited to this market because of the diverse motivations or preferences of firms (Roosenboom \& van Dijk, 2009). Accordingly, we focus on the cross-listing location choices of these firms to delineate the effect of LOF on their cross-listing decisions.

The international business literature agrees that firms inevitably face LOF when competing across national borders (Zaheer, 1995, Zaheer \& Mosakowski, 1997). Foreign firms are new entrants in the host market and must overcome their inevitable unfamiliarity with foreign institutions or customers. Therefore, these firms must collect and analyze knowledge to adapt to new foreign markets, and such process requires substantial time and cost; by contrast, their local competitors in the host market do not face such challenges (Caves, 1971, Petersen \& Pedersen, 2002). Recently, there is growing recognition that LOF exists beyond product market domain and is applicable to the capital market domain as well (Bell, Filatotchev, \& Rasheed, 2012). Based on the idea that cross-country distance has multiple dimensions (Berry, Guillén, \& Zhou, 2010, Lee, Hemmert, \& Kim, 2014), we identify four major national distances institutional, economic, geographic, and cultural distance - as important sources of LOF in cross-listing location decision. We contend that firms tend to cross-list in locations with less LOF. 
At the same time, we suggest that the preference for the cross-listing location choices of firms with similar degree levels of institutional, economic, geographical, and cultural distances vary depending on firm's sensitivity toward LOF. We focus on family ownership, which constitute a ubiquitous ownership structure among firms around the world (La Porta, Lopez-de-Silanes, Shleifer, \& Vishny, 1999), as an important factor that intensifies the effect of LOF on cross-listing location choice. Family owners prioritize non-financial goals that align with their interests; thus, they are averse to risks that threaten their stock of affect-related values that they derive from their ownership positions (GómezMejía, Haynes, Núñez-Nickel, Jacobson, \& Moyano-Fuentes, 2007). LOF, which is a key source of risk for firms that compete in foreign capital markets, is likely to be more burdensome for family owners. Although the moderating factors for LOF in product markets have been extensively investigated in the international business literature, we still know little about the contingencies under which the influence of LOF can vary in the capital market (Bell et al., 2012). We expect that firms with a higher level of family ownership have higher chances of cross-listing in countries with lower levels of institutional, economic, geographic, and cultural distance.

Based on a sample of 536 cross-listings from 28 countries directed toward 8 target markets (i.e., Australia, Canada, Luxembourg, Germany, Singapore, Switzerland, the UK, and the US). we find empirical support for our arguments. Firms are likely to choose cross-listing location with lower LOF, and this tendency is intensified for firms with family ownership. This paper provides several contributions. First, we test the LOF constructs in the financing context. The institutional, economic, geographic, and cultural distance variables, which represent multidimensional national distances, are often employed in the foreign market investment decision literature (Ambos \& Håkanson, 2014, Hutzschenreuter, Pedersen, \& Volberda, 2007). Our findings support the idea that factors frequently used to proxy the LOF in product market are also applicable to capital market (Bell, Filatotchev, \& Rasheed, 2012), as cross-listing firms face LOF when entering their target capital markets. Second, family ownership affects the target capital market choices of firms. Although previous studies have acknowledged the tendency of family owners to avoid risks in international contexts, most of these studies have analyzed how such risk aversion is manifested in investments in foreign markets (Bhaumik, Driffield, \& Pal, 2010, Gallo \& Pont, 1996, Gallo, Tàpies, \& Cappuyns, 2004, Kontinen \& Ojala, 2010, Majocchi \& Strange, 2012, Pukall \& Calabrò, 2014). We contribute to the literature by emphasizing that ownership structure must also be considered when analyzing the foreign capital market participation of firms. Third, in contrast to studies that explicitly consider multiple cross-listing destinations and apply multinomial logit regression in analyzing the characteristics of target markets (e.g., Pagano, Röell, \& Zechner, 2002, Sarkissian \& Schill, 2004, Saudagaran \& Biddle, 1995), we employ an alternative-specific conditional logit model (asclogit) to simultaneously test the effects of LOF, target-market-specific, and firm-specific factors in the multiple choice context. Hence, this model enables us to test the joint effects of country- and firm-level factors on cross-listing location choice.

The paper is structured as follows. Section 2 discusses how LOF is related to cross-listing in foreign capital markets and how the four types of national distances act as sources of LOF. Section 3 discusses the influence of family ownership on cross-listing location choice considering the risk-averse characteristics of family owners. Section 4 presents the sample, variables, and empirical results. Section 5 concludes this study by discussing our major findings and contributions to the literature.

\section{LITERATURE REVIEW AND HYPOTHESIS DEVELOPMENT}

\subsection{Liability of Foreignness and Cross-Listing Location}

Firms that attempt to enter a new foreign market face higher costs than local firms (e.g., Calhoun, 2002, Caves, 1971, Hennart, 1982, Hymer, 1976, Zaheer, 1995). LOF is broadly defined as all additional costs that firms face in a foreign market, thereby lowering the competitive advantage of foreign firms over local firms (Eden \& Miller, 2004, Zaheer, 1995). LOF increases as foreign firms face considerable unfamiliarity and relational hazards (Eden \& Miller, 2004). LOF may come from various sources, such as differences in geographic distance, culture, institution, or economy (e.g., Calhoun, 2002, Mezias, 2002, Rosenzweig \& Singh, 1991, Sethi \& Guisinger, 2002, Zaheer, 1995). Although these observations have been limited to product markets, the LOF concept has been recently introduced in the context of foreign capital market participation. For example, the framework of Bell, Filatotchev, and Rasheed (2012) identifies several factors that lead to LOF in capital markets, including institutional distance, information asymmetry, unfamiliarity, and cultural differences. Foreign firms face substantially high costs of raising capital in equity, debt, or 
venture capital markets when faced with LOF. In a similar vein, we argue that LOF is relevant for cross-listing decision, which is the decision to issue equity in a foreign stock market.

Although cross-listing offers unique opportunities to firms that aim to devise an international portfolio to diversify their country-specific risks, the attraction of investors toward "familiar" domestic stocks implies that foreign firms are often challenged when participating in foreign capital markets with higher LOF (Aggarwal, Erel, Stulz, \& Williamson, 2010, Blass \& Yafeh, 2001). The "home bias" of investors has been supported in the literature (French \& Poterba, 1991, Hejazi, 2007, Tesar \& Werner, 1995). By analyzing the US equity holdings of over 3,000 non-US-based mutual funds from 22 countries, $\mathrm{Ke}, \mathrm{Ng}$, and Wang (2010) demonstrate that fund managers tend to include the stocks of US firms that are actually doing business in their home countries. Similarly, Coval and Moskowitz (1999) report that US investment managers prefer locally headquartered firms. Tesar and Werner (1995) show securities transactions across countries are more frequent when countries are geographically and economically proximate, showing the home bias force prevails over portfolio diversification motives. Therefore, the preference of investors for familiar foreign stocks creates a barrier for cross-listing firms. The costs that foreign firms bear in capital markets are further aggravated because these firms are situated in an unfamiliar market environment. Such environment forces these firms to comply with the rules and regulations of their target capital markets, as well as manage their relationships with local financial intermediaries, in the cross-listing process.

Accordingly, we suggest that foreign firms are likely to be selective as to where to cross-list depending on the four underlying factors of national distance (i.e., institutional, economic, geographic, and cultural distance) that serve as antecedents to LOF that they face in each target capital market. We apply a multidimensional approach to national distance and focus on its four dimensions of national distance because each captures unique aspects of LOF (Ambos \& Håkanson, 2014, Hutzschenreuter, Pedersen, \& Volberda, 2007, Shaver, Mitchell, \& Yeung, 1997). Even though the uncertainty and unfamiliarity that are reflected in LOF can erode over time as firms participate in foreign markets (Calhoun, 2002), these firms face the highest LOF at the initial stage of selecting which foreign capital market to enter.

First, institutional distance increases LOF by increasing the costs for foreign firms that participate in foreign markets because significant institutional differences can challenge firms in establishing their legitimacy in foreign markets (Bell, Filatotchev, \& Rasheed, 2012). For instance, a foreign firm from an institutionally distant country experiences major differences in the general legal or regulatory environments, i.e. the rules supporting capital market participants such as accounting systems, or regulations for investor protections. If the target country has stronger institutional environment, it is likely that costs involved in cross-listing is higher. Saudagaran and Biddle (1995) suggest that multinational firms are less likely to cross-list in foreign capital markets with stricter accounting practices and legal restrictions because doing so will entail high costs for these firms to meet the high standards of these markets. Inversely, cross-listing firms may come from countries with relatively strong institutional environments. In this case, local investors may perceive that these firms are cross-listing to enjoy private benefits in weaker institutional environments (Saudagaran, 1988, Saudagaran \& Biddle, 1992, Saudagaran \& Biddle, 1995). Moreover, these investors may lack the necessary knowledge or process to value the stocks of these foreign firms. In sum, cross-listing in institutionally distant countries increases the burden of foreign firms.

Second, cross-listing stocks in an economically distant country increases LOF because information channels are less established between the two countries (Håkanson \& Ambos, 2010: p.197). Economic distance, which refers to the size of trade between countries, determines the level of information flow between the home and target countries; thus, investors can accumulate information about foreign firms by frequently transacting with foreign buyers or sellers (Ports \& Reys, 2005). If both the home and target markets have limited economic contact, then the firms face high information costs and LOF. By contrast, if two countries are actively trading, then these countries demonstrate a high information flow and firms achieve substantial exposure to the target market along with the increasing information spillovers from the product market to the capital market. Local investors are provided access to information and face low information costs when evaluating a foreign firm (Bell, Filatotchev, \& Rasheed, 2012); in fact, Portes and Rey (2005) argue that the ease of cross-border equity transaction is closely related to information flow. As foreign firms experience difficulties in making themselves more visible to local investors (Bruner, Chaplinsky, \& Ramchand, 2004) and investors in capital market are likely to face uncertainty regarding the cross-listed firms' expected market behaviors when information flow is limited (Sarkissian \& Schill, 2004), foreign firms should face lower levels of LOF in foreign capital markets in less economically distant countries because local investors tend to favor foreign firms in 
which the two countries' economies are closely linked (Dahlquist, Pinkowitz, Stulz, \& Williamson, 2003, Sarkissian \& Schill, 2004).

Third, firms tend to experience higher LOF in geographically distant countries because cross-border capital flows can be explained using a "gravity model" in which one important finding is that "informational frictions are positively correlated with distance (Portes \& Rey, 2005: p.270). As physical distance is closely related to the ease of economic exchange, the findings that a vast majority of firms' global activities are more regional rather than global on a wider scale is not surprising (Rugman \& Verbeke, 2004). Unlike economic distance, physical distance implies familiarity between countries. Although a low economic distance leads to low information costs, firms and investors may still be familiar with nearby countries (Bell, Filatotchev, \& Rasheed, 2012). The gravity model, which has been conventionally applied to goods trade, can also be applied to financial products (e.g., stocks) because geographically close countries have high familiarity and easy information exchange and communication. The finance literature empirically shows that investors tend to hold stocks of firms that are located in geographically close countries (e.g., Coval \& Moskowitz, 1999, Grinblatt \& Keloharju, 2001). Hence, we suggest that higher geographic distance increases LOF.

Fourth, cross-listing in culturally distant countries can increase LOF for foreign firms. Cultural distance plays an important role in the decision of foreign firms in entering the local capital market where they have to integrate into the "local" information network. The cultural values or norms of foreign capital markets with identifiable cultural differences cannot be easily understood. Gray, Kang, and Yoo (2013) find that the national culture affects the costs of equity capital (i.e., assessment of company risk by capital providers). It is more difficult for investors to analyze the prospects of a cross-listed firm because of the difficulties in assessing culturally different management practices or strategies (Calhoun, 2002); therefore, these investors prefer the stocks of foreign firms with low cultural distance (Dodd, Frijns, \& Gilbert, 2013). Sarkissian and Schill (2004) argue that cultural proximity facilitates the understanding or analysis of firms, and then empirically show that cross-listing activities are frequently observed in countries with similar language or historical heritage (e.g., colonial ties). Also, Grinblatt and Keloharju (2000) empirically show that investors tend to trade stocks of foreign firms that share a common language and have chief executives of the same cultural background.

Following above arguments that institutional, economic, geographic, and cultural distance influences the extent of LOF that foreign firms face in the decision of cross-listing in foreign capital markets, we hypothesize that firms should display preferences for cross-listing in countries with less LOF.

Hypothesis 1(a): Firms are likely to cross-list in a country with a lower institutional distance.

Hypothesis 1(b): Firms are likely to cross-list in a country with a lower economic distance.

Hypothesis 1(c): Firms are likely to cross-list in a country with a lower geographic distance.

Hypothesis 1(d): Firms are likely to cross-list in a country with a lower cultural distance.

\subsection{Moderating Effect of Family Ownership on Cross-Listing Location Decision}

Following that a majority of firms around the world maintains family influence in the governance structure of the firm, family ownership constitutes a ubiquitous organizational form and is highly prevalent even among large publicly held firms (Chakrabarty, 2009, La Porta, Lopez-de-Silanes, Shleifer, \& Vishny, 1999). Family ownership warrants special attention because family owners pursue non-financial goals that can potentially diverge from the financial goals of other non-family owners (Gómez-Mejía, Haynes, Núñez-Nickel, Jacobson, \& Moyano-Fuentes, 2007). Family-owned firms are characterized by a unique vision of corporate longevity with the intention of sustaining family influence across generations of the family (Chua, Chrisman, \& Sharma, 1999). Therefore, instead of maximizing financial returns, family owners primarily aim to maintain family control and protect their stock of affect-related values that they derive from their businesses (Gómez-Mejía, Cruz, Berrone, \& De Castro, 2011). However, such preference makes family owners averse to risks that result from potentially profitable business decisions that threaten the perpetuation of their family dynasty (Miller \& Le Breton-Miller, 2014). As family owners have more discretion 
to act unilaterally (Carney, 2005), their tendencies to be risk averse have the potential to influence their firms' strategy in foreign markets.

Previous studies have examined the tendency of family owners to avoid risk in international contexts, with most studies assessing how such risk aversion is manifested in their foreign market investments. Family ownership results in limited international investments (Bhaumik, Driffield, \& Pal, 2010, Gallo, Tàpies, \& Cappuyns, 2004) and low levels of international diversification as measured by the distribution of international sales (Gómez-Mejía, Makri, \& Kintana, 2010, Majocchi \& Strange, 2012). Other studies have analyzed how family ownership influences the investment processes in foreign markets. Family-owned firms not only invest in foreign markets later and slower than non-family-owned firms (Gallo \& Pont, 1996) but also tend to do so sequentially and start out by internationalizing to geographically or culturally close countries (Kontinen \& Ojala, 2010). The risk aversion of family owners is also manifested in their choice of entry modes into foreign markets; in particular, they tend to choose conservative strategies that require less resources and a lower risk of relinquishing their control (Pukall \& Calabrò, 2014).

Although family-owned firms may invest less in foreign markets than non-family-owned firms, previous findings suggest that family owners do not completely shy away from participating in foreign markets (Banalieva \& Eddleston, 2011). Instead, family owners find ways to reduce the risks in foreign markets because LOF that pervades their participation in these markets can be particularly burdensome (Johanson \& Vahlne, 1977). This observation is also applicable in the financing context in which firms expand into foreign markets by listing in foreign exchanges. The additional investments in financial, managerial, and knowledge resources for overcoming LOF can be burdensome for family-owned firms because they often lack such resources (Hitt, Tihanyi, Miller, \& Connelly, 2006, Sciascia, Mazzola, Astrachan, \& Pieper, 2012, Zaheer \& Mosakowski, 1997).

We expect that investors would be more likely to discount family-owned firms because family owners pursue their family goals along with their financial goals and do not constantly maximize shareholder wealth. Investors are aware the family owners may sacrifice profitable investment opportunities to retain family control across generations (Bertrand \& Schoar, 2006, Casson, 1999), and may invest in industries or brands that have emotional value for the family legacy even if it lacks business rationales (Zellweger \& Astrachan, 2008). The emphasis on non-financial goals can also drive family owners to make long-term investments that can potentially benefit their future generations yet do not create short-term payoffs for non-family shareholders (Block, 2010, Tagiuri \& Davis, 1992). Therefore, familyowned firms are less attractive options to be included in investment portfolios even among foreign firms because investors typically hold a short-term orientation and opt to devise profitable investment portfolios.

Therefore, although family-owned firms choose to cross-list in foreign capital markets to reap the associated benefits, these firms will show unique investment patterns by preferring to cross-list in locations with less risk. That is, familyowned firms should be highly sensitive to the difficulties that are imposed by LOF when cross-listing in foreign capital markets. Therefore, family ownership is expected to be associated with preferences to cross-list in foreign capital markets with even lower institutional, economic, geographic, and cultural distance. Following these arguments, we present the following hypotheses.

Hypothesis 2(a): Family-owned firms are more likely to cross-list in a country with a lower institutional distance compared to non-family-owned firms

Hypothesis 2(b): Family-owned firms are more likely to cross-list in a country with a lower economic distance compared to non-family-owned firms

Hypothesis 2(c): Family-owned firms are more likely to cross-list in a country with a lower geographic distance compared to non-family-owned firms

Hypothesis 2(d): Family-owned firms are more likely to cross-list in a country with a lower cultural distance compared to non-family-owned firms 
Figure 1. Theoretical Framework

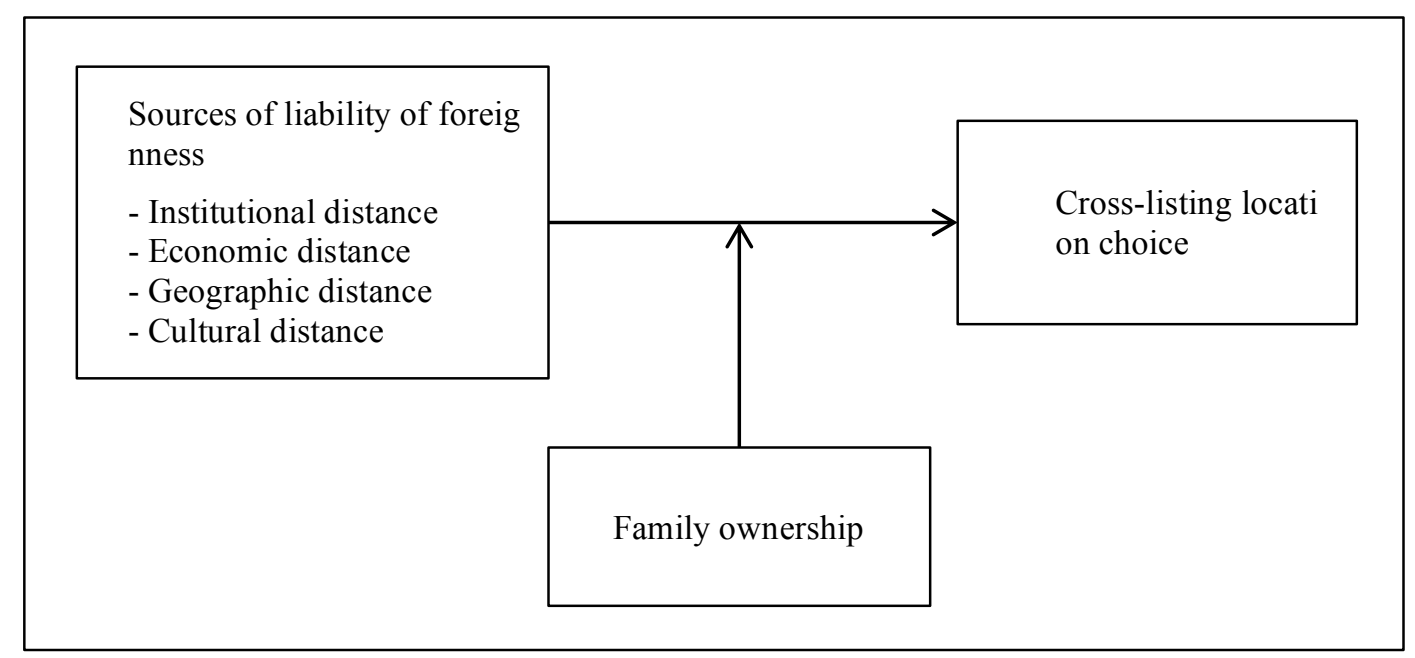

\section{DATA AND EMPIRICAL ANALYSIS}

\subsection{Samples}

Data on cross-listings from 1994 to 2008 are collected from the SDC Platinum provided by Thomson Reuters. To control the potential effects of previous cross-listings on cross-listing location decision, we identify all ordinary common stock issuances by firms that have only begun listing their stocks on a foreign exchange. We exclude financial firms and firms that are established in tax havens, such as Bermuda or the Cayman Islands, because these firms tend to be physically located elsewhere. We also exclude exchanges that may be attributed to at least two countries. For example, even though Euronext, which is formed by a merger of exchanges in France, the Netherlands, and Belgium, is physically located in the Netherlands, firms from France and Belgium can list their stocks on Euronext as if they are listing in their home countries. By using the cross-listing transactions without missing data as our variables, our final sample comprises 536 cross-listings from 28 home countries with 8 target countries (i.e., Australia, Canada, Luxembourg, Germany, Singapore, Switzerland, the UK, and the US).

\subsection{Empirical Model}

We adopt the asclogit model originally developed by McFadden (1974). Chung, Cho, and Kim (2015) identify asclogit as the most appropriate econometric specification when the choice model requires controlling for both choice- and firm-specific variables. The conditional logit model only allows the testing of choice-specific variables because firmspecific variables do not vary across the choice options. By contrast, the asclogit allows the testing of both choiceand firm-specific variables. For example, the asclogit can test for the effects of candidate and voter characteristics on the election outcomes (e.g., Dow and Endersby, 2004).

We construct an eight location choice set for each cross-listing of a firm. The actual cross-listing location has a value of 1 , whereas the other non-selected locations have a value of 0 . In each choice set, the firm-specific variables do not vary, whereas the country-level variables vary. We estimate the following random utility model:

$$
U_{i j}=\alpha^{\prime} X_{i j}+\beta_{j}^{\prime} Z_{i}+\varepsilon_{i j},
$$

where $U_{i j}$ is the random utility of firm $i$ from choosing cross-listing location $j, X_{i j}$ is the vector of values of the attributes of target country $j, Z_{i}$ is the vector of firm-specific variables for firm $i, \alpha$ is the coefficient that is identical across the target countries, $\beta_{j}$ is the vector of coefficients that differ across the target countries, and $\varepsilon_{i j}$ is the error term. The probability that a certain location will be chosen can be expressed as follows (McFadden, 1974): 


$$
P_{i j}=\frac{e^{\alpha^{\prime} X_{i j}+\beta_{j}^{\prime} Z_{i}}}{\sum_{k=0}^{8} e^{\alpha^{\prime} X_{i j}+\beta_{j}^{\prime} Z_{i}}} .
$$

\subsection{Variables}

\subsubsection{Independent Variables}

Following Meyer, Estrin, Bhaumik, and Peng (2009) and Gubbi, Aulakh, Ray, Sarkar, and Chittoor (2010), we measure the Institutional distance between the countries of the target and acquiring firms using the economic freedom index of the Heritage Foundation. This index includes four dimensions that are relevant to the cross-listing context. Business freedom shows the ability to start, operate, and close a business, which captures the overall burden of regulation and the efficiency of the government in the regulatory process. Trade freedom is a composite measure of the absence of tariff and nontariff barriers that affect the import and export of goods and services. Investment freedom measures how individuals and firms can move their resources into and out of specific activities within and across the country's borders. Financial freedom measures the banking efficiency and independence of the financial sector from government control and interference. This measure also reflects how banks can freely extend credit, accept deposits, and conduct operations in foreign currencies (Heritage Foundation, 2013). Following Kogut and Singh (1988), we calculate Institutional distance by determining the variances across these dimensions, and then obtain the arithmetic averages of the institutional dimensions. In particular, we compute Institutional distance as follows:

$$
\text { Institutional distance }_{j}=\sum_{i=1}^{4} \frac{\left\{\left(I_{i A}-I_{i T}\right)^{2} / V_{\mathrm{i}}\right\}}{4}
$$

where $I_{i A}$ is the acquirer's score on the Heritage Foundation's $i$ th institutional dimension, $I_{i T}$ is the target firm's score on the Heritage Foundation's $i$ th institutional dimension, and $V_{\mathrm{i}}$ is the variance of the dimension score.

Following Sarkissian and Schill (2004), we measure Economic distance by scaling the annual exports from the home country to the target country by the total exports of the former. We obtain the imports and exports data from the Direction of Trade database of the International Monetary Fund (IMF). We define Geographic distance as the physical distance between the capitals of the home and target countries (Chung et al., 2015). We construct the Cultural distance using Hofstede's (1991) national culture index, which is based on the differences between two countries in terms of four cultural dimensions (i.e., power distance, uncertainty avoidance, masculinity/femininity, and individualism). We correct this index following the same method for constructing Institutional distance.

\subsubsection{Moderating Variable}

We construct the Family ownership variable using the WorldScope database. This variable takes the value of 1 when the major shareholders include at least one natural person. Otherwise, this variable takes a value of 0 . Although familyowned firms can be identified through either family ownership or management participation by family members (Villalonga \& Amit, 2006), we follow the former approach because of data availability. Moreover, nearly $90 \%$ of firms in our sample have over $10 \%$ family ownership, which is large enough to control a public firm as proposed in the finance literature (e.g., La Porta, Lopez-de-Silanes, \& Shleifer, 1999). Among the 536 firms in our sample, 258 are family-owned and 278 are non-family-owned.

\subsubsection{Control Variables}

Apart from family ownership, we control for other firm-level characteristics that may influence the choice of crosslisting market. We include the natural logarithm of Tobin's $q$, which is defined as the market value of equity plus the book value of total liabilities scaled by the book value of total assets. We also control for OROA (operating income scaled by total assets), Firm size (log value of total assets), and Debt ratio before cross-listing. We include Proceeds (log value of cross-listing proceeds) in the cross-listing for each firm. The firm-level variables are obtained from the SDC Platinum and WorldScope databases. 
We control for additional stock-exchange-specific characteristics. Turnover is the annualized monthly trading of domestic shares scaled by domestic market capitalization, whereas Market capitalization is the size of stock market capitalization scaled by GDP. We obtain these variables from the World Federation of Exchanges (WFE) and the IMF. We also control for Inward stock foreign direct investment (FDI) obtained from the United Nations Conference on Trade and Development. We include Gross spread, which is defined as the average of difference between public offering and underwriting prices to control for the expected cost of cross-listing in a particular country.

\subsection{Empirical Results}

Table 1 shows the number of cross-listings for each home-target country pair. Although most foreign firms (43\%) prefer to cross-list in the US because of its largest stock market in the world, the table also suggests that over $50 \%$ of firms have cross-listed their stocks on non-US markets. We use the US as our base line country for calculating the likelihood to cross-list in a certain country is U.S. Table 2 reports the summary of target country-specific and firmspecific variables.

Table 1. Number of Cross-Listings by Home and Target Country

\begin{tabular}{|c|c|c|c|c|c|c|c|c|c|}
\hline \multirow[b]{2}{*}{$\begin{array}{l}\text { Home } \\
\text { Country }\end{array}$} & \multicolumn{9}{|c|}{ Target Country } \\
\hline & Australia & Canada & Germany & Luxembourg & Singapore & Switzerland & UK & US & Total \\
\hline Argentina & 0 & 0 & 0 & 0 & 0 & 0 & 1 & 4 & 5 \\
\hline Australia & 0 & 5 & 0 & 0 & 0 & 0 & 18 & 2 & 25 \\
\hline Austria & 0 & 0 & 6 & 0 & 0 & 2 & 1 & 0 & 9 \\
\hline Brazil & 0 & 0 & 0 & 0 & 0 & 0 & 0 & 7 & 7 \\
\hline Canada & 0 & 0 & 0 & 0 & 0 & 0 & 13 & 33 & 46 \\
\hline Chile & 0 & 0 & 0 & 0 & 0 & 0 & 0 & 10 & 10 \\
\hline China & 0 & 0 & 0 & 0 & 48 & 0 & 7 & 39 & 94 \\
\hline France & 0 & 0 & 0 & 0 & 0 & 0 & 0 & 10 & 10 \\
\hline Germany & 0 & 0 & 0 & 0 & 0 & 0 & 3 & 5 & 8 \\
\hline Greece & 0 & 0 & 0 & 0 & 1 & 0 & 2 & 11 & 14 \\
\hline Hong Kong & 0 & 0 & 0 & 0 & 30 & 0 & 3 & 7 & 40 \\
\hline India & 0 & 0 & 0 & 12 & 0 & 0 & 11 & 5 & 28 \\
\hline Indonesia & 0 & 0 & 0 & 0 & 2 & 0 & 0 & 0 & 2 \\
\hline Ireland & 0 & 0 & 0 & 0 & 0 & 0 & 22 & 5 & 27 \\
\hline Israel & 0 & 0 & 2 & 0 & 1 & 2 & 9 & 22 & 36 \\
\hline Italy & 0 & 0 & 0 & 0 & 0 & 2 & 2 & 2 & 6 \\
\hline Mexico & 0 & 0 & 0 & 0 & 0 & 0 & 0 & 6 & 6 \\
\hline Netherlands & 0 & 0 & 4 & 0 & 0 & 1 & 7 & 14 & 26 \\
\hline New Zealand & 3 & 0 & 0 & 0 & 0 & 0 & 0 & 1 & 4 \\
\hline Russia & 0 & 0 & 0 & 0 & 0 & 0 & 10 & 5 & 15 \\
\hline Singapore & 1 & 0 & 1 & 0 & 0 & 0 & 0 & 2 & 4 \\
\hline South Africa & 1 & 1 & 0 & 0 & 0 & 0 & 4 & 1 & 7 \\
\hline South Korea & 0 & 0 & 0 & 2 & 2 & 0 & 5 & 10 & 19 \\
\hline Sweden & 0 & 0 & 0 & 0 & 0 & 0 & 6 & 5 & 11 \\
\hline Switzerland & 0 & 0 & 2 & 0 & 0 & 0 & 2 & 3 & 7 \\
\hline Taiwan & 0 & 0 & 0 & 4 & 1 & 0 & 2 & 4 & 11 \\
\hline UK & 4 & 0 & 0 & 0 & 0 & 0 & 0 & 19 & 23 \\
\hline US & 0 & 4 & 1 & 0 & 0 & 2 & 29 & 0 & 36 \\
\hline Total & 9 & 10 & 16 & 18 & 85 & 9 & 157 & 232 & 536 \\
\hline Percentage & $1.7 \%$ & $1.9 \%$ & $3.0 \%$ & $3.4 \%$ & $15.9 \%$ & $1.7 \%$ & $29.3 \%$ & $43.3 \%$ & $100.0 \%$ \\
\hline
\end{tabular}


Table 2. Description of Variables

\begin{tabular}{|c|c|c|c|c|c|}
\hline Variable & $\mathbf{N}$ & mean & std. & $\min$ & $\max$ \\
\hline \multicolumn{6}{|c|}{ Liability of Foreignness } \\
\hline Institutional distance & 536 & 1.487 & 1.623 & 0.027 & 6.245 \\
\hline Economic distance & 536 & 0.155 & 0.214 & 0.000 & 0.877 \\
\hline Geographic distance & 536 & 8.585 & 1.039 & 5.875 & 10.833 \\
\hline Cultural distance & 536 & 1.411 & 1.378 & 0.021 & 5.145 \\
\hline \multicolumn{6}{|c|}{ Target Country-specific } \\
\hline Turnover & 536 & 1.407 & 0.893 & 0.002 & 6.333 \\
\hline Market capitalization & 536 & 1.520 & 0.556 & 0.538 & 3.355 \\
\hline Inward stock FDI & 536 & 13.538 & 1.583 & 0.000 & 15.083 \\
\hline Gross spread & 536 & 8.600 & 3.979 & 2.988 & 14.850 \\
\hline \multicolumn{6}{|l|}{ Firm-specific } \\
\hline Family ownership & 536 & 0.481 & 0.500 & 0 & 1 \\
\hline Tobin's $q$ & 536 & 1.330 & 1.179 & -1.743 & 6.523 \\
\hline OROA & 536 & -0.060 & 1.122 & -20.938 & 1.214 \\
\hline Firm size & 536 & 4.439 & 2.168 & -1.749 & 10.312 \\
\hline Debt ratio & 536 & 0.266 & 0.331 & 0.000 & 2.179 \\
\hline Proceeds & 536 & 3.725 & 1.521 & -2.303 & 6.902 \\
\hline
\end{tabular}

Table 3 reports the correlations among LOF, target market-specific variables, and firm-specific variables. The four variables that represent the degree of LOF (i.e., institutional, economic, geographical, and cultural distance) are correlated, except for the relationship between institutional and geographic distance. To avoid multicollinearity issues, we include these variables separately in our analyses.

Table 4 reports the effect of LOF on cross-listing location decision. A single alternative-specific conditional logit model reports two sets of results. The first set (see columns (1) to (5) of Table 4) reports the effect of LOF and target market-specific variables. For example, we can argue that significant negative value of Institutional distance implies firms' tendency to cross-list in institutionally close country. The second set (see columns with country names) shows the effect of firm-specific variables on choosing a specific target market. We only report the results of the column (5) specification for firm-specific variables because of limited space. For example, we can argue that firms that want to raise more capital through higher proceeds in cross-listing tend to cross-list less in Australia. As its key advantage, the asclogit model enables us to analyze the determinants of cross-listing location decision while controlling for firmspecific variables.

All the LOF variables have significant expected signs (see columns (1) to (4) of Table 4). The negative signs for Institutional distance, Geographic distance, and Cultural distance can be interpreted that firms prefer cross-listing location with lower distance, whereas the positive signs for Economic distance implies that firms prefer economically close countries. Our results show that firms prefer to cross-list in familiar locations, thereby supporting H1(a), (b), (c), and (d). These results are consistent with Bell, Filatotchev, and Rasheed (2012), which propose that the LOF concept is applicable in the capital market as well. When we include all four national distances in one model, significance of geographic distance variable erodes and institutional distance loses significance. When we see the coefficient for each target country, family ownership does not necessarily have a strong effect on the choice of a particular destination. Given that we use the US as the base choice for our model, the preceding findings indicate that firms with a large Tobin's $q$, size, and proceeds prefer to cross-list in the US than in other target countries. 
Table 3. Correlation between Variables

\begin{tabular}{|c|c|c|c|c|c|c|c|c|}
\hline & & 1 & 2 & 3 & 4 & 5 & 6 & 7 \\
\hline 1 & $\begin{array}{l}\text { Institutional } \\
\text { distance }\end{array}$ & & & & & & & \\
\hline 2 & $\begin{array}{l}\text { Economic } \\
\text { distance }\end{array}$ & $\begin{array}{l}-0.2682 \\
(0.000)\end{array}$ & & & & & & \\
\hline 3 & $\begin{array}{l}\text { Geographic } \\
\text { distance }\end{array}$ & $\begin{array}{c}0.0685 \\
(0.117)\end{array}$ & $\begin{array}{l}-0.1939 \\
(0.000)\end{array}$ & & & & & \\
\hline 4 & $\begin{array}{l}\text { Cultural } \\
\text { distance }\end{array}$ & $\begin{array}{c}0.3925 \\
(0.000)\end{array}$ & $\begin{array}{l}-0.0738 \\
(0.088)\end{array}$ & $\begin{array}{c}0.2651 \\
(0.000)\end{array}$ & & & & \\
\hline 5 & Turnover & $\begin{array}{l}-0.0246 \\
(0.570)\end{array}$ & $\begin{array}{c}0.3551 \\
(0.000)\end{array}$ & $\begin{array}{c}0.3506 \\
(0.000)\end{array}$ & $\begin{array}{c}0.3087 \\
(0.000)\end{array}$ & & & \\
\hline 6 & $\begin{array}{l}\text { Market } \\
\text { capitalization }\end{array}$ & $\begin{array}{c}0.3125 \\
(0.000)\end{array}$ & $\begin{array}{l}-0.2441 \\
(0.000)\end{array}$ & $\begin{array}{l}-0.1896 \\
(0.000)\end{array}$ & $\begin{array}{l}-0.2132 \\
(0.000)\end{array}$ & $\begin{array}{l}-0.2568 \\
(0.000)\end{array}$ & & \\
\hline 7 & Inward stock FDI & $\begin{array}{l}-0.048 \\
(0.268)\end{array}$ & $\begin{array}{c}0.3158 \\
(0.000)\end{array}$ & $\begin{array}{r}0.3169 \\
(0.000)\end{array}$ & $\begin{array}{c}0.2281 \\
(0.000)\end{array}$ & $\begin{array}{c}0.6093 \\
(0.000)\end{array}$ & $\begin{array}{l}-0.2114 \\
(0.000)\end{array}$ & \\
\hline 8 & Gross spread & $\begin{array}{c}0.1842 \\
(0.000)\end{array}$ & $\begin{array}{l}-0.1859 \\
(0.000)\end{array}$ & $\begin{array}{r}0.0977 \\
(0.025)\end{array}$ & $\begin{array}{c}0.0622 \\
(0.151)\end{array}$ & $\begin{array}{c}0.1086 \\
(0.012)\end{array}$ & $\begin{array}{c}0.3199 \\
(0.000)\end{array}$ & $\begin{array}{r}0.1233 \\
(0.004)\end{array}$ \\
\hline 9 & Family ownership & $\begin{array}{c}0.105 \\
(0.015)\end{array}$ & $\begin{array}{l}-0.1316 \\
(0.002)\end{array}$ & $\begin{array}{l}-0.0151 \\
(0.729)\end{array}$ & $\begin{array}{l}-0.0767 \\
(0.076)\end{array}$ & $\begin{array}{l}-0.0233 \\
(0.591)\end{array}$ & $\begin{array}{r}0.2277 \\
(0.000)\end{array}$ & $\begin{array}{l}-0.0854 \\
(0.048)\end{array}$ \\
\hline 10 & Tobin's $q$ & $\begin{array}{c}0.0203 \\
(0.638)\end{array}$ & $\begin{array}{l}-0.0209 \\
(0.629)\end{array}$ & $\begin{array}{r}0.0367 \\
(0.401)\end{array}$ & $\begin{array}{c}0.0195 \\
(0.658)\end{array}$ & $\begin{array}{c}0.1213 \\
(0.005)\end{array}$ & $\begin{array}{c}0.0704 \\
(0.104)\end{array}$ & $\begin{array}{c}0.147 \\
(0.001)\end{array}$ \\
\hline 11 & OROA & $\begin{array}{c}0.1312 \\
(0.002)\end{array}$ & $\begin{array}{c}0.0142 \\
(0.743)\end{array}$ & $\begin{array}{l}-0.0328 \\
(0.453)\end{array}$ & $\begin{array}{c}0.1142 \\
(0.008)\end{array}$ & $\begin{array}{c}0.0069 \\
(0.873)\end{array}$ & $\begin{array}{c}0.0812 \\
(0.060)\end{array}$ & $\begin{array}{l}-0.0299 \\
(0.490)\end{array}$ \\
\hline 12 & Firm size & $\begin{array}{c}0.1856 \\
(0.000)\end{array}$ & $\begin{array}{c}0.1595 \\
(0.000)\end{array}$ & $\begin{array}{c}0.1049 \\
(0.016)\end{array}$ & $\begin{array}{c}0.3436 \\
(0.000)\end{array}$ & $\begin{array}{c}0.126 \\
(0.004)\end{array}$ & $\begin{array}{l}-0.128 \\
(0.003)\end{array}$ & $\begin{array}{r}0.0717 \\
(0.097)\end{array}$ \\
\hline 13 & Debt ratio & $\begin{array}{l}-0.0543 \\
(0.210)\end{array}$ & $\begin{array}{c}0.0301 \\
(0.487)\end{array}$ & $\begin{array}{l}-0.0918 \\
(0.036)\end{array}$ & $\begin{array}{l}-0.0016 \\
(0.970)\end{array}$ & $\begin{array}{r}0.0267 \\
(0.538)\end{array}$ & $\begin{array}{l}-0.0665 \\
(0.124)\end{array}$ & $\begin{array}{c}0.0095 \\
(0.826)\end{array}$ \\
\hline 14 & Proceeds & $\begin{array}{c}0.1053 \\
(0.015)\end{array}$ & $\begin{array}{c}0.1739 \\
(0.000)\end{array}$ & $\begin{array}{c}0.1666 \\
(0.000)\end{array}$ & $\begin{array}{c}0.3393 \\
(0.000)\end{array}$ & $\begin{array}{c}0.3343 \\
(0.000)\end{array}$ & $\begin{array}{l}-0.0749 \\
(0.083)\end{array}$ & $\begin{array}{c}0.2265 \\
(0.000)\end{array}$ \\
\hline
\end{tabular}

Table 3 continued

\begin{tabular}{|c|c|c|c|c|c|c|c|c|}
\hline & & 1 & 2 & 3 & 4 & 5 & 6 & 7 \\
\hline 9 & Family ownership & $\begin{array}{c}0.1522 \\
(0.000)\end{array}$ & & & & & & \\
\hline 10 & Tobin's $q$ & $\begin{array}{r}0.1605 \\
(0.000)\end{array}$ & $\begin{array}{c}0.1226 \\
(0.005)\end{array}$ & & & & & \\
\hline 11 & OROA & $\begin{array}{l}-0.0026 \\
(0.952)\end{array}$ & $\begin{array}{c}0.0223 \\
(0.607)\end{array}$ & $\begin{array}{l}-0.3519 \\
(0.000)\end{array}$ & & & & \\
\hline 12 & Firm size & $\begin{array}{l}-0.1776 \\
(0.000)\end{array}$ & $\begin{array}{l}-0.2909 \\
(0.000)\end{array}$ & $\begin{array}{l}-0.5078 \\
(0.000)\end{array}$ & $\begin{array}{c}0.2885 \\
(0.000)\end{array}$ & & & \\
\hline 13 & Debt ratio & $\begin{array}{c}0.0618 \\
(0.153)\end{array}$ & $\begin{array}{l}-0.1113 \\
(0.010)\end{array}$ & $\begin{array}{c}0.139 \\
(0.001)\end{array}$ & $\begin{array}{l}-0.2372 \\
(0.000)\end{array}$ & $\begin{array}{l}-0.0028 \\
(0.948)\end{array}$ & & \\
\hline 14 & Proceeds & $\begin{array}{r}0.0046 \\
(0.915) \\
\end{array}$ & $\begin{array}{l}-0.2095 \\
(0.000) \\
\end{array}$ & $\begin{array}{l}-0.0252 \\
(0.560) \\
\end{array}$ & $\begin{array}{c}0.1128 \\
(0.009) \\
\end{array}$ & $\begin{array}{r}0.6035 \\
(0.000) \\
\end{array}$ & $\begin{array}{r}0.0453 \\
(0.295) \\
\end{array}$ & \\
\hline
\end{tabular}


Table 4. Analysis of Effect of Liability of Foreignness in Cross-listing Listing Location Choice

\begin{tabular}{|c|c|c|c|c|c|}
\hline & (1) & (2) & (3) & (4) & (5) \\
\hline \multicolumn{6}{|c|}{ Liability of Foreignness } \\
\hline Institutional distance & $\begin{array}{l}0.7380^{* * *} \\
(0.000)\end{array}$ & & & & $\begin{array}{l}-0.2114 \\
(0.268)\end{array}$ \\
\hline Economic distance & & $\begin{array}{l}3.1577^{* * *} \\
(0.000)\end{array}$ & & & $\begin{array}{l}2.1586^{* * *} \\
(0.000)\end{array}$ \\
\hline Geographic distance & & & $\begin{array}{l}-0.6180^{* * *} \\
(0.000)\end{array}$ & & $\begin{array}{l}-0.2043 \dagger \\
(0.071)\end{array}$ \\
\hline Cultural distance & & & & $\begin{array}{l}-0.6362^{* * *} \\
(0.000)\end{array}$ & $\begin{array}{l}-0.5764^{* * *} \\
(0.000)\end{array}$ \\
\hline \multicolumn{6}{|c|}{ Target Country-specific } \\
\hline Turnover & $\begin{array}{l}-0.4906^{* *} \\
(0.003)\end{array}$ & $\begin{array}{l}-0.4604^{* *} \\
(0.005)\end{array}$ & $\begin{array}{l}-0.4721 * * \\
(0.005)\end{array}$ & $\begin{array}{l}-0.4003^{*} \\
(0.012)\end{array}$ & $\begin{array}{l}-0.3635^{*} \\
(0.021)\end{array}$ \\
\hline Market capitalization & $\begin{array}{l}-0.0393 \\
(0.849)\end{array}$ & $\begin{array}{l}-0.1596 \\
(0.434)\end{array}$ & $\begin{array}{l}-0.2394 \\
(0.257)\end{array}$ & $\begin{array}{l}-0.3781 \dagger \\
(0.094)\end{array}$ & $\begin{array}{l}-0.3817 \dagger \\
(0.096)\end{array}$ \\
\hline Inward stock FDI & $\begin{array}{c}0.0556 \\
(0.380)\end{array}$ & $\begin{array}{r}0.0517 \\
(0.417)\end{array}$ & $\begin{array}{r}0.0831 \\
(0.211)\end{array}$ & $\begin{array}{c}0.0803 \\
(0.208)\end{array}$ & $\begin{array}{c}0.0864 \\
(0.186)\end{array}$ \\
\hline Gross spread & $\begin{array}{l}-1.1392^{* * *} \\
(0.000)\end{array}$ & $\begin{array}{l}-1.0169^{* * *} \\
(0.000)\end{array}$ & $\begin{array}{l}-1.0507^{* * *} \\
(0.000)\end{array}$ & $\begin{array}{l}-0.9903^{* * *} \\
(0.000)\end{array}$ & $\begin{array}{l}-0.8982^{* * *} \\
(0.001)\end{array}$ \\
\hline Wald chi2 & 213.6 & 217.5 & 233.3 & 227.8 & 242.6 \\
\hline Log likelihood & -536.5 & -525.4 & -519.4 & -496.0 & -474.6 \\
\hline Prob $>$ chi 2 & 0 & 0 & 0 & 0 & 0 \\
\hline Observations & 536 & 536 & 536 & 536 & 536 \\
\hline
\end{tabular}

$\dagger$ if $\mathrm{p}<0.10, *$ if $\mathrm{p}<0.05 ; * *$ if $\mathrm{p}<0.01 ; * *$ if $\mathrm{p}<0.001$

Table 4 continued

\begin{tabular}{|c|c|c|c|c|c|c|c|c|}
\hline & Australia & Canada & Germany & Luxembourg & Singapore & Switzerland & UK & US \\
\hline \multicolumn{9}{|c|}{ Firm-specific } \\
\hline $\begin{array}{l}\text { Family } \\
\text { ownership }\end{array}$ & $\begin{array}{l}0.4022 \\
(0.587)\end{array}$ & $\begin{array}{l}0.8116 \\
(0.286)\end{array}$ & $\begin{array}{l}0.1853 \\
(0.754)\end{array}$ & $\begin{array}{c}-0.9526 \\
(0.109)\end{array}$ & $\begin{array}{l}0.2645 \\
(0.570)\end{array}$ & $\begin{array}{c}-0.6174 \\
(0.421)\end{array}$ & $\begin{array}{c}-0.2426 \\
(0.401)\end{array}$ & \multirow{7}{*}{$\begin{array}{l}\text { Base } \\
\text { choice }\end{array}$} \\
\hline Tobin's $q$ & $\begin{array}{c}-0.9546^{*} \\
(0.031)\end{array}$ & $\begin{array}{c}-0.6065 \dagger \\
(0.099)\end{array}$ & $\begin{array}{c}-0.8587^{* *} \\
(0.007)\end{array}$ & $\begin{array}{c}-1.2852^{* *} \\
(0.006)\end{array}$ & $\begin{array}{c}-0.9884^{* * *} \\
(0.000)\end{array}$ & $\begin{array}{r}-0.1805 \\
(0.633)\end{array}$ & $\begin{array}{c}-0.4975^{* *} \\
(0.001)\end{array}$ & \\
\hline OROA & $\begin{array}{c}-1.2570^{*} \\
(0.035)\end{array}$ & $\begin{array}{c}-0.4334 \\
(0.745)\end{array}$ & $\begin{array}{l}0.7022 \\
(0.584)\end{array}$ & $\begin{array}{l}1.6941 \\
(0.378)\end{array}$ & $\begin{array}{c}5.6074^{* * *} \\
(0.000)\end{array}$ & $\begin{array}{c}-0.6611 \\
(0.513)\end{array}$ & $\begin{array}{r}-1.2180^{*} \\
(0.025)\end{array}$ & \\
\hline Firm size & $\begin{array}{l}-0.3189 \\
(0.212)\end{array}$ & $\begin{array}{r}-0.3479 \\
(0.222)\end{array}$ & $\begin{array}{c}-0.6615^{* *} \\
(0.006)\end{array}$ & $\begin{array}{c}-0.1493 \\
(0.460)\end{array}$ & $\begin{array}{c}-0.5108^{* *} \\
(0.009)\end{array}$ & $\begin{array}{c}-0.2488 \\
(0.367)\end{array}$ & $\begin{array}{c}-0.2789^{* *} \\
(0.009)\end{array}$ & \\
\hline Debt ratio & $\begin{array}{c}-0.4339 \\
(0.766)\end{array}$ & $\begin{array}{r}-2.1495 \\
(0.265)\end{array}$ & $\begin{array}{r}-0.1273 \\
(0.917)\end{array}$ & $\begin{array}{l}1.0974 \\
(0.314)\end{array}$ & $\begin{array}{l}1.1791 \\
(0.245)\end{array}$ & $\begin{array}{l}0.3668 \\
(0.741)\end{array}$ & $\begin{array}{l}0.4393 \\
(0.413)\end{array}$ & \\
\hline Proceeds & $\begin{array}{c}-0.9373^{* *} \\
(0.001)\end{array}$ & $\begin{array}{c}-0.4460 \\
(0.135)\end{array}$ & $\begin{array}{c}-0.6315^{* *} \\
(0.010)\end{array}$ & $\begin{array}{c}-0.3503 \\
(0.160)\end{array}$ & $\begin{array}{c}-0.7026^{* * *} \\
(0.000)\end{array}$ & $\begin{array}{c}-0.3529 \\
(0.317)\end{array}$ & $\begin{array}{c}-0.4963^{* * *} \\
(0.000)\end{array}$ & \\
\hline Constant & $\begin{array}{r}2.6881 \dagger \\
(0.065) \\
\end{array}$ & $\begin{array}{r}0.5078 \\
(0.739) \\
\end{array}$ & $\begin{array}{c}2.6822 * \\
(0.026)\end{array}$ & $\begin{array}{r}0.8161 \\
(0.546) \\
\end{array}$ & $\begin{array}{c}5.5192^{* * *} \\
(0.000)\end{array}$ & $\begin{array}{c}0.1928 \\
(0.900) \\
\end{array}$ & $\begin{array}{c}3.4263^{* * *} \\
(0.000)\end{array}$ & \\
\hline
\end{tabular}

$\dagger$ if $\mathrm{p}<0.10, *$ if $\mathrm{p}<0.05 ; * *$ if $\mathrm{p}<0.01 ; * * *$ if $\mathrm{p}<0.001$ 
Table 5. Analysis of Moderating Effect of Family Ownership in Cross-listing Listing Location Choice

\begin{tabular}{|c|c|c|c|c|}
\hline & (1) & (2) & (3) & (4) \\
\hline \multicolumn{5}{|l|}{ Liability of Foreignness } \\
\hline Institutional distance & $\begin{array}{l}-1.0016^{* * *} \\
(0.000)\end{array}$ & & & \\
\hline Institutional distance $*$ Family ownership & $\begin{array}{c}0.4235 \\
(0.198)\end{array}$ & & & \\
\hline Economic distance & & $\begin{array}{l}2.4679^{* * *} \\
(0.000)\end{array}$ & & \\
\hline Economic distance $*$ Family ownership & & $\begin{array}{l}2.4044^{*} \\
(0.042)\end{array}$ & & \\
\hline Geographic distance & & & $\begin{array}{l}-0.4475^{* * *} \\
(0.000)\end{array}$ & \\
\hline Geographic distance * Family ownership & & & $\begin{array}{l}-0.3906^{*} \\
(0.023)\end{array}$ & \\
\hline Cultural distance & & & & $\begin{array}{l}-0.4706^{* * *} \\
(0.000)\end{array}$ \\
\hline Cultural distance $*$ Family ownership & & & & $\begin{array}{l}-0.3504^{*} \\
(0.039)\end{array}$ \\
\hline \multicolumn{5}{|l|}{ Target Country-specific } \\
\hline \multirow{2}{*}{ Turnover } & $-0.4906^{* *}$ & $-0.4438^{* *}$ & $-0.4699^{* *}$ & $-0.3981^{*}$ \\
\hline & $(0.003)$ & $(0.007)$ & $(0.005)$ & $(0.013)$ \\
\hline \multirow{2}{*}{ Market capitalization } & -0.0321 & -0.1668 & -0.2761 & $-0.4225+$ \\
\hline & $(0.876)$ & $(0.415)$ & $(0.196)$ & $(0.065)$ \\
\hline \multirow{2}{*}{ Inward stock FDI } & 0.0557 & 0.0526 & 0.0852 & 0.0727 \\
\hline & $(0.380)$ & $(0.407)$ & $(0.196)$ & $(0.250)$ \\
\hline \multirow{2}{*}{ Gross spread } & $-1.1336^{* * *}$ & $-0.9952^{* * *}$ & $-1.0410^{* * *}$ & $-0.9871^{* * *}$ \\
\hline & $(0.000)$ & $(0.000)$ & $(0.000)$ & $(0.000)$ \\
\hline Wald chi2 & 214.5 & 219.9 & 236.7 & 224.2 \\
\hline Log likelihood & -535.7 & -523.2 & -516.7 & -493.7 \\
\hline Prob $>$ chi 2 & 0 & 0 & 0 & 0 \\
\hline Observations & 536 & 536 & 536 & 536 \\
\hline
\end{tabular}

Table 5 continued

\begin{tabular}{|c|c|c|c|c|c|c|c|c|}
\hline & Australia & Canada & Germany & Luxembourg & Singapore & Switzerland & UK & US \\
\hline \multicolumn{9}{|l|}{ Firm-specific } \\
\hline Family ownership & $\begin{array}{l}0.5022 \\
(0.495)\end{array}$ & $\begin{array}{l}0.7372 \\
(0.324)\end{array}$ & $\begin{array}{l}0.3189 \\
(0.581)\end{array}$ & $\begin{array}{c}-1.1701+ \\
(0.060)\end{array}$ & $\begin{array}{l}0.8100 \\
(0.126)\end{array}$ & $\begin{array}{c}-0.5493 \\
(0.471)\end{array}$ & $\begin{array}{l}0.0092 \\
(0.973)\end{array}$ & \multirow{7}{*}{$\begin{array}{l}\text { base } \\
\text { choice }\end{array}$} \\
\hline Tobin's $q$ & $\begin{array}{c}-0.8708^{*} \\
(0.042)\end{array}$ & $\begin{array}{c}-0.5336 \\
(0.137)\end{array}$ & $\begin{array}{c}-0.7203^{*} \\
(0.019)\end{array}$ & $\begin{array}{c}-1.1463^{*} \\
(0.012)\end{array}$ & $\begin{array}{c}-1.0369^{* * *} \\
(0.000)\end{array}$ & $\begin{array}{c}-0.1012 \\
(0.784)\end{array}$ & $\begin{array}{c}-0.3929^{* *} \\
(0.006)\end{array}$ & \\
\hline OROA & $\begin{array}{c}-1.1299^{*} \\
(0.041)\end{array}$ & $\begin{array}{r}-0.3867 \\
(0.767)\end{array}$ & $\begin{array}{l}0.9299 \\
(0.453)\end{array}$ & $\begin{array}{l}1.9460 \\
(0.312)\end{array}$ & $\begin{array}{c}6.2016^{* * *} \\
(0.000)\end{array}$ & $\begin{array}{c}-0.5233 \\
(0.590)\end{array}$ & $\begin{array}{c}-1.0603^{*} \\
(0.034)\end{array}$ & \\
\hline Firm size & $\begin{array}{r}-0.2649 \\
(0.288)\end{array}$ & $\begin{array}{c}-0.3512 \\
(0.220)\end{array}$ & $\begin{array}{c}-0.6324^{* *} \\
(0.006)\end{array}$ & $\begin{array}{c}-0.1191 \\
(0.547)\end{array}$ & $\begin{array}{c}-0.5119^{* *} \\
(0.007)\end{array}$ & $\begin{array}{c}-0.2408 \\
(0.379)\end{array}$ & $\begin{array}{c}-0.2500^{*} \\
(0.013)\end{array}$ & \\
\hline Debt ratio & $\begin{array}{l}-0.2986 \\
(0.836)\end{array}$ & $\begin{array}{c}-2.0405 \\
(0.300)\end{array}$ & $\begin{array}{r}-0.0535 \\
(0.962)\end{array}$ & $\begin{array}{l}1.1137 \\
(0.275)\end{array}$ & $\begin{array}{l}1.1250 \\
(0.259)\end{array}$ & $\begin{array}{c}0.3302 \\
(0.761)\end{array}$ & $\begin{array}{l}0.4585 \\
(0.369)\end{array}$ & \\
\hline Proceeds & $\begin{array}{c}-0.9050^{* *} \\
(0.002)\end{array}$ & $\begin{array}{c}-0.3709 \\
(0.205)\end{array}$ & $\begin{array}{c}-0.5848^{*} \\
(0.015)\end{array}$ & $\begin{array}{c}-0.3198 \\
(0.203)\end{array}$ & $\begin{array}{c}-0.7176^{* * *} \\
(0.000)\end{array}$ & $\begin{array}{c}-0.3080 \\
(0.382)\end{array}$ & $\begin{array}{c}-0.4613^{* * *} \\
(0.000)\end{array}$ & \\
\hline Constant & $\begin{array}{c}1.4593 \\
(0.296)\end{array}$ & $\begin{array}{l}-0.3258 \\
(0.825)\end{array}$ & $\begin{array}{c}1.9030+ \\
(0.083)\end{array}$ & $\begin{array}{r}-0.0623 \\
(0.961)\end{array}$ & $\begin{array}{c}4.7146^{* * *} \\
(0.000)\end{array}$ & $\begin{array}{l}-0.5587 \\
(0.703)\end{array}$ & $\begin{array}{c}2.6046^{* * *} \\
(0.000)\end{array}$ & \\
\hline
\end{tabular}


Table 5 shows how family ownership moderates the effects of institutional, economic, geographic, and cultural distance variables. Although family ownership has an insignificant effect on institutional distance (see column (1)), this variable has a significant moderating effect on economic, geographic, and cultural distance. These results support $\mathrm{H} 2$ (b), (c), and (d), thereby suggesting that family-owned firms favor foreign capital markets with lower LOF. The insignificant moderating effect of family ownership on the relationship between institutional distance and cross-listing decision can be partially explained by the fact that institutional distance has an implication on the governance structure of family-owned firms. Entering an institutionally stringent capital market can be burdensome for family owners because family-owned firms tend to pursue both family and financial goals. Family owners may expect that the level of real or perceived power, which allows them to influence corporate decisions, will decline when they cross-list in an institutionally developed country. Therefore, the absolute value of institutional distance is a less relevant concept for family-owned firms.

\section{DISCUSSION AND CONCLUSION}

This study examines how LOF and family ownership influence the decision of firms to participate in the foreign capital market by utilizing cross-listing location choice context. We propose that if LOF - exists in foreign capital market as well, then the firms will be less likely to choose foreign capital with higher LOF. Our empirical results show that various dimensions, i.e., institutional, economic, geographic, and cultural distance, act as a burden for firms that enter new foreign capital markets. One avenue for future research is that the level of LOF may eventually erode as the firm accumulates experience in the host market. That is, a firm may be able to gain cost advantage after it enters a foreign capital market despite the prevailing LOF. To test such changes in the LOF level, future studies may utilize the secondary stock issues of firms in the foreign capital market that they enter.

We further show that family owners are more sensitive to LOF; as a result, they prefer new foreign capital market with less LOF. This finding suggests that family-owned firms are considerably sensitive to LOF that they face when entering a foreign market. Our study is consistent with the family business literature that posits that the unique priorities of family owners can shape the strategic decisions of their firms (Fiss \& Zajac, 2004, Gómez-Mejía, Haynes, Núñez-Nickel, Jacobson, \& Moyano-Fuentes, 2007); in particular, family owners tend to make risk-averse decisions to protect the affect-related values that they derive from their ownership positions. While family-owned firms do engage in cross-listing, family owners are more likely to interpret LOF as an even greater risk and display unique investment patterns by preferring cross-listing locations with less risk. Our results suggests that while family owners should participate in foreign capital markets, they would still do in ways that can lessen the associated risks. Furthermore, to the best of our knowledge, the unique risk preferences of family owners has never been investigated in the context of cross-listing location decisions. Therefore, the current study expands the research on the influence of family ownership in the international financing context. Future studies on family ownership and LOF may analyze the institutional differences between the home and target countries of family-owned firms. Our empirical results on the moderating effect of family ownership show that institutional distance has insignificant effect on cross-listing location choice for family-owned firms. We expect that family-owned firms focus on the relative strength of the target market's institution instead of the absolute level of institutional differences between the home and target countries. Since family owners prefer to maintain their voices and control rights in their firms to achieve private benefits, it may be burdensome for them to enter foreign capital market with strong institution where they face stricter regulation and higher investor protection.

\section{AUTHOR BIOGRAPHIES}

He Soung Ahn (first author) is a doctoral candidate in Management at the Korea University. Her research interests include mergers and acquisition strategies, the role of family control in strategic decision-making, and strategic decision-making from an institutional perspective.

Hyejin Cho (corresponding author) is a doctoral candidate in International Business at the Korea University. Her research interests include cross-border mergers and acquisitions, cross-listing, foreign initial public offering, and global tax management. E-mail: hyejinstory@gmail.com 


\section{REFERENCES}

Aggarwal, R., Erel, I., Stulz, R., \& Williamson, R. (2010). Differences in governance practices between US and foreign firms: Measurement, causes, and consequences. Review of Financial Studies, 23(3), 3131-3169.

Ambos, B. \& Håkanson, L. (2014). The concept of distance in international management research. Journal of International Management, 20(1), 1-7.

Banalieva, E. R. \& Eddleston, K. A. (2011). Home-region focus and performance of family firms: The role of family vs nonfamily leaders. Journal of International Business Studies, 42(8), 1060-1072.

Bell, R. G., Filatotchev, I., \& Rasheed, A. A. (2012). The liability of foreignness in capital markets: Sources and remedies. Journal of International Business Studies, 43(2), 107-122.

Berry, H., Guillén, M. F., \& Zhou, N. (2010). An institutional approach to cross-national distance. Journal of International Business Studies, 41(9), 1460-1480.

Bertrand, M. \& Schoar, A. (2006). The role of family in family firms. Journal of Economic Perspectives, 20(2), 73-96.

Bhaumik, S. K., Driffield, N., \& Pal, S. (2010). Does ownership structure of emerging-market firms affect their outward FDI? The case of the Indian automotive and pharmaceutical sectors. Journal of International Business Studies, 41(3), $437-$ 450.

Blass, A. \& Yafeh, Y. (2001). Vagabond shoes longing to stray: Why foreign firms list in the United States. Journal of Banking \& Finance, 25(3), 555-572.

Block, J. (2010). Family management, family ownership, and downsizing: Evidence from S\&P 500 firms. Family Business Review, 23(2), 109-130.

Bruner, R., Chaplinsky, S., \& Ramchand, L. (2004). US-bound IPOs: issue costs and selective entry. Financial Management: 33(3), 39-60.

Calhoun, M. A. (2002). Unpacking liability of foreignness: identifying culturally driven external and internal sources of liability for the foreign subsidiary. Journal of International Management, 8(3), 301-321.

Carney, M. (2005). Corporate governance and competitive advantage in family-controlled firms. Entrepreneurship Theory and Practice, 29(3), 249-265.

Casson, M. (1999). The economics of the family firm. Scandinavian Economic History Review, 47(1), 10-23.

Caves, R. E. (1971). International corporations: The industrial economics of foreign investment. Economica, 38(149), 1-27.

Chakrabarty, S. (2009). The influence of national culture and institutional voids on family ownership of large firms: A country level empirical study. Journal of International Management, 15(1), 32-45.

Chua, J. H., Chrisman, J. J., \& Sharma, P. (1999). Defining the family business by behavior. Entrepreneurship Theory and Practice, 23(4), 19-39.

Chung, J., Cho, H., \& Kim, W. (2015). Is cross-listing a commitment mechanism?: The choice of destinations and family ownership. Corporate Governance: An International Review, 23(4), 307-330.

Cooper, I. \& Kaplanis, E. (1994). Home bias in equity portfolios, inflation hedging, and international capital market equilibrium. Review of Financial Studies, 7(1), 45-60.

Coval, J. D. \& Moskowitz, T. J. (1999). Home bias at home: Local equity preference in domestic portfolios. Journal of Finance, 54(6), 2045-2073.

Dahlquist, M., Pinkowitz, L., Stulz, R. M., \& Williamson, R. 2003. Corporate governance and the home bias. Journal of Financial and Quantitative Analysis, 38(1), 87-110.

Dodd, O., Frijns, B., \& Gilbert, A. (2015). On the role of cultural distance in the decision to cross-list. European Financial Management, 21(4), 706-741

Eden, L. \& Miller, S. R. (2004). Distance matters: liability of foreignness, institutional distance and ownership strategy. Advances in International Management, 16: 187-221.

Fiss, P. C. \& Zajac, E. J. (2004). The diffusion of ideas over contested terrain: The (non) adoption of a shareholder value orientation among German firms. Administrative Science Quarterly, 49(4), 501-534.

French, K. R. \& Poterba, J. M. (1991). Were Japanese stock prices too high? Journal of Financial Economics, 29(2), $337-363$.

Gómez-Mejía, L. R., Cruz, C., Berrone, P., \& De Castro, J. (2011). The bind that ties: Socioemotional wealth preservation in family firms. The Academy of Management Annals, 5(1), 653-707.

Gómez-Mejía, L. R., Haynes, K. T., Núñez-Nickel, M., Jacobson, K. J. L., \& Moyano-Fuentes, J. (2007). Socioemotional wealth and business risks in family-controlled firms: Evidence from Spanish olive oil mills. Administrative Science Quarterly, 52(1), 106-137.

Gómez-Mejía, L. R., Makri, M., \& Kintana, M. L. (2010). Diversification decisions in family-controlled firms. Journal of Management Studies, 47(2), 223-252.

Gallo, M. A. \& Pont, C. G. (1996). Important factors in family business internationalization. Family Business Review, 9(1), 4559.

Gallo, M. Á., Tàpies, J., \& Cappuyns, K. (2004). Comparison of family and nonfamily business: Financial logic and personal preferences. Family Business Review, 17(4), 303-318.

Gray, S. J., Kang, T., \& Yoo, Y. K. (2013). National culture and international differences in the cost of equity capital. Management International Review, 53(6), 899-916. 
Grinblatt, M. \& Keloharju, M. (2001). How distance, language, and culture influence stockholdings and trades. Journal of Finance, 56(3), 1053-1073.

Grinblatt, M. \& Keloharju, M. (2000). The investment behavior and performance of various investor types: a study of Finland's unique data set. Journal of Financial Economics, 55(1), 43-67.

Gubbi, S. R., Aulakh, P. S., Ray, S., Sarkar, M., \& Chittoor, R. (2010). Do international acquisitions by emerging-economy firms create shareholder value? The case of Indian firms. Journal of International Business Studies, 41(3), 397-418.

Håkanson, L. \& Ambos, B. (2010). The antecedents of psychic distance. Journal of International Management, 16(3), 195-210.

Hejazi, W. (2007). Reconsidering the concentration of US MNE activity: Is it global, regional or national? Management International Review, 47(1), 5-27.

Hennart, J.-F. (1982). A theory of multinational enterprise: Univ of Michigan Pr.

Heritage Foundation. (2013). 2013 Index of economic freedom. Washington DC: Heritage Foundation.

Hitt, M. A., Tihanyi, L., Miller, T., \& Connelly, B. (2006). International diversification: Antecedents, outcomes, and moderators. Journal of Management, 32(6), 831-867.

Hofstede, G. (1991). Cultures and organizations: Software of the mind. London, UK: McGraw-Hill.

Hutzschenreuter, T., Pedersen, T., \& Volberda, H. W. (2007). The role of path dependency and managerial intentionality: A perspective on international business research. Journal of International Business Studies, 38(7), 1055-1068.

Hymer, S. H. (1976). The international operations of national firms: A study of direct foreign investment: MIT press Cambridge, MA.

Johanson, J. \& Vahlne, J.-E. (1977). The internationalization process of the firm - a model of knowledge development and increasing foreign market commitments. Journal of International Business Studies, 8(1), 23-32.

Karolyi, G. A. (2006). The world of cross-listings and cross-listings of the world: Challenging conventional wisdom. Review of Finance, 10(1), 99-152.

Ke, D., Ng, L., \& Wang, Q. (2010). Home bias in foreign investment decisions. Journal of International Business Studies, 41(6), 960-979.

Kogut, B. \& Singh, H. (1988). The effect of national culture on the choice of entry mode. Journal of International Business Studies, 19(3), 411-432.

Kontinen, T. \& Ojala, A. (2010). The internationalization of family businesses: A review of extant research. Journal of Family Business Strategy, 1(2), 97-107.

La Porta, R., Lopez-de-Silanes, F., \& Shleifer, A. (1999). Corporate ownership around the world. Journal of Finance, 54(2), 471517.

La Porta, R., Lopez-de-Silanes, F., Shleifer, A., \& Vishny, R. (1999). The quality of government. Journal of Law, Economics, and Organization, 15(1), 222-279.

Lee, Y., Hemmert, M., \& Kim, J. (2014). What drives the international ownership strategies of Chinese firms? The role of distance and home-country institutional factors in outward acquisitions. Asian Business \& Management, 13(3), 197225.

Majocchi, A. \& Strange, R. (2012). International diversification: The impact of ownership structure, the market for corporate control and board independence. Management International Review, 52(6), 879-900.

McFadden, D. (1974). Conditional logit analysis of qualitative choice behavior.In Zarembka, P., (Ed.), Frontiers in Econometrics. New York: Academic Press.

Meyer, K. E., Estrin, S., Bhaumik, S., \& Peng, M. W. (2009). Institutions, resources, and entry strategies in emerging economies. Strategic Management Journal, 30(1), 61-80.

Mezias, J. M. (2002). How to identify liabilities of foreignness and assess their effects on multinational corporations. Journal of International Management, 8(3), 265-282.

Miller, D. \& Le Breton-Miller, I. (2014). Deconstructing socioemotional wealth. Entrepreneurship Theory and Practice, 38(4), 713-720.

Pagano, M., Röell, A. A., \& Zechner, J. (2002). The geography of equity listing: Why do companies list abroad? Journal of Finance, 57(6), 2651-2694.

Petersen, B. \& Pedersen, T. (2002). Coping with liability of foreignness: different learning engagements of entrant firms. Journal of International Management, 8(3), 339-350.

Portes, R. \& Rey, H. (2005). The determinants of cross-border equity flows. Journal of international Economics, 65(2), $269-296$.

Pukall, T. J. \& Calabrò, A. (2014). The internationalization of family firms A critical review and integrative model. Family Business Review, 27(2), 103-125.

Roosenboom, P. \& van Dijk, M. A. (2009). The market reaction to cross-listings: Does the destination market matter? Journal of Banking \& Finance, 33(10), 1898-1908.

Rosenzweig, P. M. \& Singh, J. V. (1991). Organizational environments and the multinational enterprise. Academy of Management Review, 16(2), 340-361.

Rugman, A. M. \& Verbeke, A. (2004). A perspective on regional and global strategies of multinational enterprises. Journal of International Business Studies, 35(1), 3-18.

Sarkissian, S. \& Schill, M. J. (2004). The overseas listing decision: New evidence of proximity preference. Review of Financial Studies, 17(3), 769-809. 
Saudagaran, S. M. (1988). An empirical study of selected factors influencing the decision to list on foreign stock exchanges. Journal of International Business Studies, 19(1), 101-127.

Saudagaran, S. M. \& Biddle, G. C. (1992). Financial disclosure levels and foreign stock exchange listing decisions. Journal of International Financial Management \& Accounting, 4(2), 106-148.

Saudagaran, S. M. \& Biddle, G. C. (1995). Foreign listing location: A study of MNCs and stock exchanges in eight countries. Journal of International Business Studies, 26(2), 319-341.

Sciascia, S., Mazzola, P., Astrachan, J. H., \& Pieper, T. M. (2012). The role of family ownership in international entrepreneurship: Exploring nonlinear effects. Small Business Economics, 38(1), 15-31.

Sethi, D. \& Guisinger, S. (2002). Liability of foreignness to competitive advantage: How multinational enterprises cope with the international business environment. Journal of International Management, 8(3), 223-240.

Shaver, J. M., Mitchell, W., \& Yeung, B. (1997). The effect of own-firm and other-firm experience on foreign direct investment survival in the United States, 1987-92. Strategic Management Journal, 18(10), 811-824.

Tagiuri, R. \& Davis, J. A. (1992). On the goals of successful family companies. Family Business Review, 5(1), 43-62.

Tesar, L. L. \& Werner, I. M. (1995). Home bias and high turnover. Journal of International Money and Finance, 14(4), 467-492.

Villalonga, B. \& Amit, R. (2006). How do family ownership, control and management affect firm value? Journal of Financial Economics, 80(2), 385-417.

Zaheer, S. (1995). Overcoming the liability of foreignness. Academy of Management Journal, 38(2), 341-363.

Zaheer, S. \& Mosakowski, E. (1997). The dynamics of the liability of foreignness: a global study of survival in financial services. Strategic Management Journal, 18(6), 439-463.

Zellweger, T. M. \& Astrachan, J. H. (2008). On the emotional value of owning a firm. Family Business Review, 21(4), $347-363$. 